\title{
Update on the Etiology, Diagnosis and Therapeutic Management of Sexual Precocity
}

revisão

\author{
Vinicius NaHime Brito \\ ana Claudia latronico \\ IVO J. P. ARNHOLD
}

Berenice BILHarinho Mendonça

Unidade de Endocrinologia do Desenvolvimento, Disciplina de Endocrinologia da Faculdade de Medicina da Universidade de São Paulo e Laboratório de Hormônios de Genética Molecular LIM/42, São Paulo, SP, Brazil

Precocious puberty is defined as the development of secondary sexual characteristics before the age of 8 years in girls and 9 years in boys. Gonadotropindependent precocious puberty (GDPP) results from the premature activation of the hypothalamic-pituitary-gonadal axis and mimics the physiological pubertal development, although at an inadequate chronological age. Hormonal evaluation, mainly through basal and $\mathrm{GnRH}$-stimulated $\mathrm{LH}$ levels shows activation of the gonadotropic axis. Gonadotropin-independent precocious puberty (GIPP) is the result of the secretion of sex steroids, independently from the activation of the gonadotropic axis. Several genetic causes, including constitutive activating mutations in the human LH-receptor gene and activating mutations in the Gs protein $\alpha$-subunit gene are described as the etiology of testotoxicosis and McCune-Albright syndrome, respectively. The differential diagnosis between GDPP and GIPP has direct implications on the therapeutic option. Long-acting gonadotropin-releasing hormone $(\mathrm{GnRH})$ analogs are the treatment of choice in GDPP. The treatment monitoring is carried out by clinical examination, hormonal evaluation measurements and image studies. For treatment of GIPP, drugs that act by blocking the action of sex steroids on their specific receptors (cyproterone, tamoxifen) or through their synthesis (ketoconazole, medroxyprogesterone, aromatase inhibitors) are used. In addition, variants of the normal pubertal development include isolated forms of precocious thelarche, precocious pubarche and precocious menarche. Here, we provide an update on the etiology, diagnosis and management of sexual precocity. (Arq Bras Endocrinol Metab 2008;52/1:18-31)

Keywords: Precocious puberty, GnRH analogs, Precocious thelarche, Precocious pu-barche, Testotoxicosis, McCune Albright syndrome.

\section{RESUMO}

\section{Atualização em etiologia, diagnóstico e manejo da precocidade sexual.}

A puberdade precoce é definida como o desenvolvimento dos caracteres sexuais secundários antes dos 8 anos nas meninas e dos 9 anos nos meninos. A puberdade precoce dependente de gonadotrofinas (PPDG) resulta da ativação prematura do eixo hipotálamo-hipófise-gonadal e mimetiza o desenvolvimento puberal fisiológico, embora em idade cronológica inadequada. A avaliação hormonal, principalmente os valores de LH basal e após estímulo com GnRH exógeno confirmam a ativação do eixo gonadotrófico. A puberdade precoce independente de gonadotrofinas (PPIG) é o resultado da secreção de esteróides sexuais independentemente da ativação do eixo gonadotrófico. Diversas causas genéticas, incluindo mutações ativadoras constitutivas no gene do receptor do LH humano e mutações ativadoras no gene da subunidade $\alpha$ da proteína $\mathrm{G}$ representam as etiologias da testotoxicose e da síndrome de McCune Albright, respectivamente. O diagnóstico diferencial entre PPDG e PPIG tem implicação direta na opção terapêutica. Análogos de $\mathrm{GnRH}$ de ação prolongada é 
o tratamento de escolha da PPDG. A monitorização do tratamento da PPDG é realizada pelo exame clínico, avaliação hormonal e exames de imagem. Para o tratamento da PPIG, são usadas drogas que bloqueiam a ação dos esteróides sexuais nos seus receptores específicos (ciproterona, tamoxifeno) ou bloqueiam a sua síntese (cetoconazol, medroxiprogesterona e inibidores da aromatase). Variantes do desenvolvimento puberal normal incluem as formas isoladas de telarca, pubarca e menarca precoces. Nesta revisão, atualizamos a etiologia, o diagnóstico e tratamento da precocidade sexual. (Arq Bras Endocrinol Metab 2008;52/1:18-31)

Descritores: Puberdade precoce; Análogos de GnRH; Telarca precoce; Pubarca precoce; Testotoxicose; Síndrome de McCune Albright.

\section{INTRODUCTION}

P RECOCIOUS PUBERTY IS DEFINED as the development of secondary sexual characteristics before the age of 8 years in the girls and 9 years in the boys, based on European longitudinal studies carried out in the 60's (1). However, the definition of the limits of chronological age that define sexual precocity was object of extensive discussion. A study including 17,000 girls suggested an adjustment in the mean age of the onset of puberty in the United States (2). In this study, based on mothers' reports and photographs, breast and/or pubic hair development was present in $27.3 \%$ of the African-American girls and in $6.7 \%$ of the white girls at 7 years of age (2). However, a review of 223 patients with sexual precocity occurring between 7 and 8 years of age in white girls and between 6 and 8 years of age in African-American girls found a non-idiopathic form of sexual precocity in $12 \%$ of the cases, indicating that the finding of sexual characteristics between 6 and 8 years is not necessarily benign and warrants investigation and follow-up (3).

When evaluating a child with a clinical picture of precocious puberty, the first step consists of the characterization of puberty as gonadotropin secretion-dependent or independent. The differential diagnosis between these two types of precocious puberty has direct implications on the therapeutic option.

\section{Classification of precocious puberty}

Gonadotropin-dependent precocious puberty (GDPP) is defined as the premature development of secondary sexual characteristics by the premature activation of the hypothalamic-pituitary-gonadal axis and gonadotro- pin-independent precocious puberty (GIPP) occurs when premature sexual development is dependent on steroid production regardless of gonadotropin secretion (Table 1). In addition to these two distinct forms of sexual precocity, three variants of the premature pubertal development can occur: isolated precocious thelarche, precocious pubarche and precocious menarche.

\section{Isolated precocious thelarche}

The term "precocious thelarche" represents the isolated unilateral or bilateral breast development with no other estrogen secretion signs. This is generally a benign clinical condition, occurring from birth to 3 years of age, presenting a spontaneous regression within months or persisting to puberty. In isolated precocious thelarche, bone age and growth velocity remain adequate for chronological age. The physiopathology of precocious thelarche is not completely clarified. Baseline serum gonadotropin and steroid levels are within normal prepubertal range, although FSH levels and inhibin B can be increased in this condition (4). Pelvic ultrasound, a noninvasive tool, may be helpful in distinguishing isolated premature thelarche from early-stage

Table 1. Classification of the precocious puberty.

Gonadotropin-dependent precocious puberty (GDPP)
Gonadotropin-independent precocious puberty (GIPP)
Variants of the normal pubertal development
Isolated precocious thelarche
Isolated precocious pubarche
Isolated precocious menarche


precocious puberty in girls (5). The follow-up of girls with precocious thelarche is mandatory, since $14 \%$ of the girls with precocious thelarche may evolve with complete sexual precocity (6). Baseline gonadotropin and estradiol levels, growth velocity and bone age should be periodically evaluated in this condition. The treatment of isolated precocious thelarche consists of advice to parents and biannual evaluation of patients to detect a possible progression into complete puberty.

\section{Isolated precocious pubarche}

This condition consists of the appearance of pubic hair before 8 years of age in girls and 9 years in boys. The development of axillary hair, increased growth velocity and slight advancement of bone age can also be observed, mainly in the first two years, with a difference of up to two years in about $16 \%$ of the cases, although progression of puberty and final height impairment were not seen. The nonclassical form of congenital virilizing adrenal hyperplasia should be ruled out by an ACTH-stimulation test. Both prematurity and small for the gestational age status, as well as overweight and obesity have been associated with precocious pubarche $(7,8)$. In addition, excess weight gain in childhood may predispose to precocious pubarche in susceptible individuals (9).

\section{Isolated precocious menarche}

It is characterized by isolated vaginal bleeding before the age of 8 years without other pubertal signs or bone age advancement. Such episodes are more frequent during the winter and do not present a cyclical character. Gonadotropin and estradiol levels are at the normal prepubertal range. A detailed clinical history as well as examination of the external genitalia is essential to rule out possible genital traumatic injuries or manipulations.

\section{GONADOTROPIN-DEPENDENT PRECOCIOUS PUBERTY}

Gonadotropin-dependent precocious puberty (GDPP) mimics the physiological pubertal development, although at an inadequate chronological age. In the male, the incresead testicular volume $>4 \mathrm{~mL}$ (or length $>2.5 \mathrm{~cm}$ ) represents the first clinical manifestation of isosexual GDPP. In the female, the increased growth velocity and thelarche are the initial events. On the other hand, gonadotropin-independent precocious pu- berty (GIPP) might lead to heterosexual precocious puberty (feminization in boys due to high estradiol secretion or virilization in girls due to high androgen production). In both isosexual and heterosexual precocious puberty, , the high steroid concentrations determine the increasing growth velocity and the bone maturation, culminating in epiphysis premature fusion. This results in excessive stature over childhood followed by short stature by adult age in non-treated cases. The estimated GDPP incidence is 1:5.000 - $1: 10.000$ (1). The occurrence of precocious puberty is more often seen in the female ( 3 to 23 -fold), mainly the idiopathic gonadotropin-dependent form (1). In the last few years, the pivotal role of the kisspeptin-GPR54 system in the stimulation of gonadotropin-releasing hormone (GnRH) neurons during puberty was demonstrated. An activating heterozygous mutation in GPR 54 (R386P) was identified in an adopted Brazilian female with GDPP; this change is not identified in individuals with normal reproductive function having Caucasian, African-American, and Hispanic origin (10,11). Additionally, an activating mutation (P74S) in the KiSS1 gene encoding GPR54's ligand, kisspeptin, was identified in a Brazilian boy with GDPP $(10,12)$. These findings represent the first genetic causes of GDPP and should be added to GDPP classification (Table 2). Several neurological causes, including hypothalamic hamartomas, central nervous system (CNS) tumors, brain development defects, inflammation and trauma, can determine sexual precocity. In the male, neurological abnomalities are responsible for $2 / 3$ of the cases of precocious puberty, and CNS tumors represent approximately $50 \%$ of the cases. These data indicate the need for an efficient neurological investigation in patients with sexual precocity, particularly in boys (1).

\section{Hypothalamic hamartomas}

Hamartomas represent a non-neoplasic congenital malformation, consisting of a heterotopic mass of hypothalamic tissue, located in the base of the brain, in the floor of the third ventricle, next to the tuber cinerium or the mamillary bodies (13). Immunohistochemistry studies revealing the presence of $\mathrm{GnRH}$-positive neurons in some hamartomas led to the hypothesis that these neurons function as a heterotopic GnRH pulse-generator (14). In contrast, in other hamartomas associated with sexual precocity, no GnRH immunoreactivity was demonstrated, but TGF $\alpha$ mRNA and protein, as well as the receptor for TGF $\alpha$, the epidermal growth factor receptor, were detected (14). Approximately 2-28\% of the patients with 
Table 2. Etiology of gonadotropin-dependent precocious puberty.

No CNS abnormalities
Idiopathic
Genetic causes (GPR54 and KiSS-1 mutations)
Secondary to the previous chronic exposure to sex steroids: (Late treatment of virilizing forms of congenital adrenal
hyperplasia, after resection of sex steroid-secreting tumors, testotoxicosis, McCune-Albright syndrome)
After exposure to endocrine disrupters
CNS abnormalities
Hypothalamic hamartoma
Tumors: astrocytoma, craniopharingeoma, ependymoma, optical or hypothalamic glyoma, LH-secreting adenoma,
pinealoma, neurofibroma, dysgerminoma
Congenital malformations: arachnoid cyst, supraselar cyst, hydrocephaly, spina bifida, septum-optical dysplasia,
myelomeningocele, vascular malformations
Acquired diseases: infections and inflammatory processes of the CNS (encephalitis and meningitis, tuberculosis and
sarcoidosis granulomas, abscesses, radiation, chemotherapy, head trauma, perinatal asphyxia)

GDPP present hypothalamic hamartomas (1). Clinically, hypothalamic hamartomas can be asymptomatic, and when symptomatic, the clinical manifestation of sexual precocity occurs in approximately $80 \%$ of the cases and is characterized by the early onset of secondary sexual characteristics $(1,13)$. Neurological manifestations can be associated with precocious puberty, with gelastic epilepsy (typical laughing seizures) being the most common feature, followed by focal and tonic-clonic seizures. On magnetic resonance imaging (MRI), a non-enhanced mass of similar intensity to the normal hypothalamus is detected (1). The therapy of GDPP due to hypothalamic hamartoma is preferably medical using depot GnRH analogs (13). Surgical treatment is reserved for large hamartomas with neurological symptoms that are difficult to control or in the rare cases of tumor growth (não seria "regrowth"?).

\section{Clinical evaluation}

Careful clinical history is important to attain the correct diagnosis. The age of onset and the rhythm of development of secondary sexual characteristics, steroid intake, CNS trauma or infections and family history of onset of puberty are valuable information. The physical examination includes the description of secondary sexual characteristics, along with testis measurement in boys and breast development in girls, as well as pubic hair development in both sexes, classifying them according to Marshall and Tanner criteria $(15,16)$. Testicular volume $>4 \mathrm{~mL}$ or length $>2.5 \mathrm{~cm}$ indicates testicular stimulation. In GDPP, testicular volume is at pubertal size, except in boys below the age of 2 years, in whom testicular volume can be still at prepubertal size. In contrast, in GIPP, although a reduced testicular volume is expected, there are some situations in which both testes have an intermediately increased size (testotoxicosis, hCG-producing tumors, adrenal testicular rests and $D A X-1$ mutation). Weight and height must be evaluated, as well as the statural age, using adequate growth curves and calculating height and weight standard deviation score (SDS) for chronological age by appropriate tables. Other physical aspects such as the presence of acne, oily skin and hair, axillary hair and odor, muscular development and presence of abdominal and pelvic masses must be evaluated. The presence of skin lesions (café-au-lait spots) can be useful in the diagnosis of McCune Albright syndrome (gonadotropin- independent precocious puberty due to autonomous ovarian cysts, café-au-lait spots and polyostotic fibrous dysplasia) or neurofibromatosis (GDPP, skin lesions and CNS glyoma).

\section{Hormonal evaluation}

The hormonal measurements in basal conditions and after stimulation with exogenous GnRH (100 mcg of GnRH, i.v) are useful in the diagnosis and differential diagnosis of precocious puberty (17). There are several available methods for gonadotropin measurements and normal values should be established for each method. The cut-off values for the immunofluorometric method (IFMA) have been established from a population of normal individuals (17). Basal LH concentrations $>0.6$ $\mathrm{U} / \mathrm{L}$ for boys and girls are considered enough to estab- 
lish the diagnosis of GDPP, which dispenses with GnRH stimulation test (17). When basal LH levels are at prepubertal range (in $37 \%$ of the girls with GDPP and $29 \%$ of the boys in our cohort of 77 children), the $\mathrm{GnRH}$ stimulation test is indicated. Serum levels of $\mathrm{LH}$ peak $>9.6 \mathrm{U} / \mathrm{L}$ in boys and $>6.9 \mathrm{U} / \mathrm{L}$ in girls after GnRH stimulation indicate the diagnosis of GDPP (17). Alternatively, LH measurement 30 to $120 \mathrm{~min}$ utes after the first administration of long-acting $\mathrm{GnRH}$ analog can substitute the classic GnRH-stimulation test, however at a higher cost (18). Depot leuprolide contains enough free leuprolide to cause a rapid rise in serum gonadotropin concentrations (19). We demonstrated that LH levels $>10 \mathrm{U} / \mathrm{L}$ (by IFMA) $2 \mathrm{hr}$ after the first depot leuprolide acetate injection are also indicative of activation of the gonadotropin axis (18). Recently, baseline and GnRH-stimulated LH levels measured by immunochemiluminometric assays (ICMA) in normal subjects demonstrated that this method seems to be more sensitive than IFMA, thereby allowing the differentiation between pubertal and prepubertal stage mainly in boys under baseline conditions, since the sensitivity of LH ICMA assay was $0.1 \mathrm{U} / \mathrm{L}$ (20). Neely et al. (21) reported that a GnRH-stimulated LH peak measured by ICMA greater than $5 \mathrm{U} / \mathrm{L}$ was indicative of maturing gonadotropin secretion, at least in female subjects, who constitute about $90 \%$ of children with early puberty. However, in that study, 2 SD above the prepubertal mean of LH peak for male and female subjects combined was 7.9 U/L (21). Finally, this study suggested that a diagnostic cut-off of $8 \mathrm{U} / \mathrm{L}$ for $\mathrm{GnRH}$-stimulated LH peak in female subjects is a more stringent, and possibly preferable, threshold for diagnosis of GDPP (21). Obviously, the criteria for diagnosis and mainly for treatment of GDPP should be a synthesis of several clinical factors, as well as the required hormonal confirmation. A review of the GnRH-stimulated LH cut-off values indicative of maturing gonadotropin secretion for the different methods is presented in Table 3. Baseline and GnRH-stimulated FSH levels are not useful for the diagnosis of GDPP, but suppressed levels indicate gonadotropin-independent precocious puberty (17). Serum testosterone is an excellent marker of sexual precocity in the male. In contrast, in the female, low estradiol concentrations do not rule out the diagnosis of precocious puberty, as a significant number of girls with sexual precocity (41\% in our cohort) had estradiol levels within the prepubertal range (17). High estradiol levels in the presence of low or suppressed gonadotropin levels strongly suggest the diagnosis of gonadotropin-independent precocious puberty (17). In boys, the measurement of the human chorionic gonadotropin (hCG) levels must be carried out with the objective of diagnosing hCG-producing gonadal and extragonadal tumors. Other important measurements include TSH, free T4 and adrenal androgen precursors.

Table 3. LH cut-off values that indicate gonadotropic axis maturation.

\begin{tabular}{|c|c|c|c|c|}
\hline Author & Protocol & $\begin{array}{l}\text { LH peak } \\
\text { time (min) }\end{array}$ & Method & Cut-off value \\
\hline Oerter KE et al, 1990 (22) & LH peak after $\mathrm{GnRH}(100 \mu \mathrm{g})$ & NA & RIA & $\begin{array}{l}>15 \mathrm{U} / \mathrm{L} \text { (girls) } \\
>25 \mathrm{U} / \mathrm{L} \text { (boys) }\end{array}$ \\
\hline Neely EK et al, $1995(21)^{*}$ & LH peak after $\mathrm{GnRH}(100 \mu \mathrm{g})$ & 30 & ICMA & $\begin{array}{l}>5 \mathrm{U} / \mathrm{L} \\
\text { (both genders) }\end{array}$ \\
\hline Cavallo A et al, 1995 (23) & LH peak after $\mathrm{GnRH}(100 \mu \mathrm{g})$ & 30,45 or 60 & IRMA & $>15 \mathrm{U} / \mathrm{L}$ \\
\hline Eckert et al, 1996 (24) & LH peak after $\mathrm{GnRH}(100 \mu \mathrm{g})$ & 40 & ICMA & $>8.0 \mathrm{U} / \mathrm{L}$ \\
\hline Brito et al, 1999 (17) & LH peak after $\mathrm{GnRH}(100 \mu \mathrm{g})$ & $30-45$ & IFMA & $\begin{array}{l}>6.9 \mathrm{U} / \mathrm{L} \text { (girls) } \\
>9.6 \mathrm{U} / \mathrm{L} \text { (boys) }\end{array}$ \\
\hline Brito et al, 2004 (18) & LH 2 hs after $3.75 \mathrm{mg}$ of depot leuprolide & 120 & IFMA & $>10 \mathrm{U} / \mathrm{L}$ (girls) \\
\hline \multirow{2}{*}{ Resende et al, $2007(20)^{*}$} & \multirow{2}{*}{ LH peak after GnRH $(100 \mu g)$} & $30-45$ & ICMA & $\begin{array}{l}>3.3 \mathrm{U} / \mathrm{L} \text { (girls) } \\
>4.1 \mathrm{U} / \mathrm{L} \text { (boys) }\end{array}$ \\
\hline & & $30-45$ & IFMA & $\begin{array}{l}>4.2 \mathrm{U} / \mathrm{L} \text { (girls) } \\
>3.3 \mathrm{U} / \mathrm{L} \text { (boys) }\end{array}$ \\
\hline
\end{tabular}

RIA: radioimmunoassay; ICMA: immunochemiluminometric assay; IFMA: immunofluorometric assay; NA: not available *Only normal subjects were included. 


\section{Image studies}

Bone age assessment by Greulich \& Pyle or Tanner methods represents a mandatory tool in diagnosis, follow-up of therapeutic efficacy and final height prediction. In the cases of sexual precocity, regardless of the etiology, bone age is advanced in relation to chronological age, except in hypothyroidism. In girls, pelvic ultrasound allows the assessment of ovarian dimensions and the detection of cysts and neoplasic processes. The anatomical evaluation of the CNS in the GDPP cases is carried out preferentially by MRI, since CT is able to identify CNS tumors, but not the smaller hamartomas.

\section{Secondary gonadotropin-dependent precocious puberty}

It is triggered by the chronic exposure to sex steroids, resulting in the acceleration of linear growth, bone age and hypothalamic maturation after the primary disease treatment. This condition generally occurs when the bone age is $10-13$ years. The main examples of this condition is GDPP that follows sexual steroid suppression in late-treated patients with virilizing congenital adrenal hyperplasia, familial male-limited precocious puberty (testotoxicosis) and McCune-Albright syndrome.

\section{Previous exposure to endocrine disrupters}

Dichlorodiphenyltrichloroethane (DDT)-derived pesticides, which are still used in developing countries, may result in premature hypothalamic maturation. Increased levels of DDT have been found in adopted girls from developing countries with precocious puberty. The proposed mechanism is that estrogen activity may suppress and mature the hypothalamus; after migration to developed countries the exposure to DDT is discontinued, resulting in an increased release of $\mathrm{GnRH}$ in those girls (25).

\section{Treatment}

Precocious puberty treatment has broad objectives, which include clinical and psychological aspects, such as detecting and treating intracranial expanding tumors, interrupting sexual maturation until the normal age for puberty onset, regressing or stabilizing sexual characteristics, suppressing the acceleration of skeletal maturation, preventing the child's emotional problems, alleviating the parents' anxiety, delaying the start of sexual activity, preventing pregnancy, reducing the risk of sexual abuse and decreasing the risk of breast cancer associated with precocious menarche. Long-acting GnRH agonist analogs are the treatment of choice in GDPP (1). They are synthetic analogs of the natural GnRH decapeptide. The site of action of such agents is the pituitary gland, leading to a reduced number of GnRH receptors in the hypophysis. Several GnRH analogs are available, such as leuprolide acetate, goserelin, tryptorelin and nafarelin, among others. There is an initial stimulation of gonadotropin synthesis and secretion, and when administered chronically, it leads to the suppression of gonadotropin production with consequent suppression of the sex steroid production (17). Chronic administration of GnRH analogs results in the regression or stabilization of secondary sexual characteristics, normalization of growth velocity and reduction of bone age advancement. The administration route and the dose used for the effective blocking of the pubertal process depend on the type of analog to be used. There are formulations for intramuscular, subcutaneous, transdermal implants or nasal administration. The adequate dose to reach a satisfactory pubertal blocking is still controversial. Our aim is to lower gonadotropin values to prepubertal levels, preventing complete gonadotropin suppression. The use of leuprolide acetate at a dose of $3.75 \mathrm{mg}$ (subcutaneous or intramuscular route) every 28 days has been widely used, with satisfactory outcomes(26). Only $4 \%$ of our precocious puberty children treated with GnRH analogs needed an increased dose $(7.5 \mathrm{mg} /$ month $)$ to control precocious puberty $(17,18)$. Over the last decade, the evidence on the safety and effectiveness of GnRH analogs administered quarterly with a 3 -fold higher dose than the monthly used analogs $(11.25 \mathrm{mg}$ of leuprolide acetate or $10.8 \mathrm{mg}$ of goserelin) represent a more comfortable option for the patient with GDPP (27-29). Recently, it was demonstrated that the subdermal GnRH analog (histrelin) implant achieves and maintains excellent suppression of peak LH and sex steroid levels for $1 \mathrm{yr}$ in children with $\operatorname{GDPP}(30,31)$. The side effects of long-acting $\mathrm{GnRH}$ analogs include: vaginal bleeding after the first doses, nausea and vasomotor symptoms due to hypoestrogenism. Local allergic reactions can be found in up to $10 \%$ of the patients (32). In these situations, the use must be discontinued and other treatment options must be instituted, such as medroxyprogesterone or cyproterone acetate. It has been demonstrated that GnRH analogs do not result in weight gain $(1,26,33)$. The treatment monitoring is 
carried out through clinical examination, hormonal evaluation and image assessment. The clinical examination must aim at verifying the stabilization or regression of the secondary sexual characteristics, the analysis of growth velocity and the examination of the injection site. The hormonal evaluation during the treatment of precocious puberty with GnRH analogs includes baseline and GnRH-stimulated measurements $(1,18)$. Baseline serum $\mathrm{LH}$ levels at prepubertal ranges $(<0.6 \mathrm{U} / \mathrm{L}$, IFMA) and sex steroids, estradiol $(<10 \mathrm{pg} / \mathrm{mL})$ in girls with previous elevated estradiol levels, and testosterone $(<14 \mathrm{ng} / \mathrm{dL})$ in boys, indicate adequate suppression of puberty (18). Evaluation at baseline conditions is recommended every 3 months, as well as a stimulation test with exogenous GnRH every 6 months (18). After GnRH-stimulation test, a value of $\mathrm{LH}<2.3 \mathrm{U} / \mathrm{L}$ suggests a good hormonal control criterion, using the IFMA method (18). Some simplified alternatives for the treatment monitoring can be used (18). A single serum sample for LH drawn 30 to 120 minutes after a treatment dose of depot leuprolide is an accurate and reliable tool to evaluate treatment efficacy in a manner directly comparable with GnRH-stimulation test $(18,19)$. We demonstrated, in a group of 18 clinically well-blocked GDPP girls, that $\mathrm{LH}$ values $<6.6 \mathrm{U} / \mathrm{L} 2$ hours after a $3.75 \mathrm{mg}$ depot leuprolide acetate injection suggest good hormonal control (18). Different LH cut-off values for GDPP monitoring, as well as different protocols, are displayed in Table 4 . Bone age must be evaluated yearly. The routine US assessment is not indicated during GDPP treatment with GnRH analogs, except when incomplete pubertal blocking or concomitant ovarian processes are suspected.

\section{Treatment withdrawal}

The chronological age for treatment withdrawal has to be considered together with the bone age, the psychological profile and the patient's and family's wishes. The best results are obtained with GnRH-analog treatment withdrawal between 12 and 12.5 years of bone age in girls and between 13 and 13.5 years in boys $(1,26)$. A meta-analysis including more than 637 GDPP girls treated with GnRH analogs showed that $75 \%$ of them have reached final height within target height range (26). When final height is compared with the predicted height at the beginning of the treatment, the best results are those obtained in patients who initiated treatment earlier (26). However, no positive effects on predicted height were obtained after treatment with GnRH analogs in girls whose puberty onset was between 8 and 10 years of chronological age (26). Fewer reports are available for males, but they point in the same direction (26,39-41). A complete reversibility of the hypothalamic-pituitary-gonadal axis suppression after GnRH-analog therapy withdrawal has been demonstrated (42). Menarche occurs at variable time periods (6-18 months) after treatment withdrawal, being more precocious in the girls who had already presented menarche before treatment (26). Bone mineral density (BMD) is, in most cases, increased for chronological age at the moment of the diagnosis and decreases during the GnRH agonist treatment or remains unchanged $(26,42,43)$. However, at long-term follow-up, BMD remains within the normal range for the females when they reach final height $(26,42,43)$.

Table 4. LH cut-off values of different methods for the monitoring of GDPP treatment with depot GnRH analogs.

\begin{tabular}{|c|c|c|c|c|}
\hline Author & Protocol & $\begin{array}{l}\text { LH peak } \\
\text { time (min) }\end{array}$ & Method & Cut-off value \\
\hline Parker KL et al, 1991 (34) & LH peak after GnRH $(100 \mu g)$ & $20-40$ & IRMA & $<1.75 \mathrm{U} / \mathrm{L}$ \\
\hline Cook JS et al, 1992 (35) & Nocturnal random LH measurement & NA & RIA & $<4.0 \mathrm{U} / \mathrm{L}$ \\
\hline Witchel SF et al, 1996 (36) & LH peak after $\mathrm{GnRH}(100 \mu \mathrm{g})$ & NA & DELFIA & $<1.75 \mathrm{U} / \mathrm{L}$ \\
\hline Lawson ML et al, 1999 (37) & LH after GnRH $(100 \mu g)$ & 40 & ICMA & $<2.0 \mathrm{U} / \mathrm{L}$ \\
\hline Bhatia et al, 2002 (19) & LH after depot leuprolide 7.5 mg & $40-60$ & ICMA & $<3.0 \mathrm{U} / \mathrm{L}$ \\
\hline Brito et al, 2004 (18) & LH after depot leuprolide 3.75 mg & 120 & IFMA & $<6.6 \mathrm{U} / \mathrm{L}$ \\
\hline Brito et al, 2004 (18) & LH after GnRH $(100 \mu g)$ & $30-45$ & IFMA & $<2.3 \mathrm{U} / \mathrm{L}$ \\
\hline Badaru et al, 2006 (38) & LH after depot leuprolide $7.5 \mathrm{mg}$ & 40 & ICMA & $<4.5 \mathrm{U} / \mathrm{L}$ \\
\hline
\end{tabular}

RIA: radioimmunoassay; ICMA: immunochemiluminometric assay; IFMA: immunofluorometric assay NA: not available 
When the suppression of the pituitary-gonadal axis results in marked growth deceleration during treatment with GnRH-a (growth velocity below the $25^{\text {th }}$ percentile for chronological age $), \mathrm{GH}(0.15 \mathrm{U} / \mathrm{Kg} / \mathrm{d})$ therapy can be associated. Two studies showed a real benefit from adding GH to GnRH-a therapy in children with decreased growth during GnRHa therapy $(44,45)$. In these two studies, the mean final height was 7.1 and $8.1 \mathrm{~cm}$ greater than the pretreatment predicted height in the first and second report, respectively, and 3.5 and $4.6 \mathrm{~cm}$ greater than the adult height reached by the control group treated with GnRH-a alone, respectively $(44,45)$.

More recently, the association of GnRH-a therapy with oxandrolone $(0.06 \mathrm{mg} / \mathrm{kg} \cdot \mathrm{d}$ by mouth $)$, a nonaromatizable androgen, was described in girls with GDPP. In this study, the mean adult height was $7.8 \mathrm{~cm}$ greater than the pretreatment predicted height and 4.5 $\mathrm{cm}$ greater than the adult height reached by the control group (46). However, this excellent result should be confirmed in other studies since the group treated with GnRH-a alone reached the lowest final height (151.9 \pm $1.2 \mathrm{~cm}$ ) of all large GDPP cohorts (46).

\section{GnRH receptor antagonists}

They immediately block the effect of GnRH and have been recently developed for clinical use. They have been currently used in assisted reproduction, but experimental studies encourage their use in GDPP treatment (47).

\section{GONADOTROPIN-INDEPENDENT PRECOCIOUS PUBERTY}

Also called precocious pseudopuberty or peripheral precocious puberty, gonadotropin-independent precocious puberty (GIPP) is the result of the precocious secretion of sex steroids, independently from the activation of the gonadotropic axis (17). The main causes of GIPP are listed in Table 5.

\section{Tumor causes}

Testicular Tumors: Leydig cell tumors represent 1-3\% of all the testicular tumors. They are generally benign; however, $10 \%$ of them can present malignant behavior. The early clinical manifestation of these tumors is precocious puberty with testicular edema, testis asymmetry accompanied or not by solid masses. The activating mutation of the LH receptor gene (LHR), Asp 578His, has been described in several patients with Leydig cell tumors (48). High levels of testosterone accompanied by prepubertal or suppressed gonadotropin levels confirm the diagnosis of GIPP. US is useful to detect testicular nodules. The surgical approach for tumor removal is the treatment of choice.

\section{Ovarian tumors}

Ovarian tumors are rare and are seldom bilateral or clinically malignant. Abdominal pain is a frequent clini-

Table 5. Etiology of Gonadotropin-Independent precocious puberty.

\author{
Exogenous use of sex steroids \\ Tumors \\ - hCG-producing tumors: hepatomas, gonadal chorioepithelioma or extragonadal teratomas. \\ - Adrenal tumors \\ - Testicular tumors \\ - Leydig cell hyperplasia or tumors \\ - Ovarian tumors \\ - Granulosa and theca cell tumors \\ Autonomous ovarian cysts \\ Severe long-term untreated primary hypothyroidism

\section{Genetic causes} \\ Inactivating mutations in CYP21A2 gene \\ Inactivating mutations in CYP1 1 and HSD3B2 genes \\ Activating mutations in the $\alpha$-subunit of the Gs protein gene (McCune-Albright syndrome) \\ Activating mutations in LH-receptor gene (LHR) (testotoxicosis) \\ Activating and inactivating mutations in the aromatase gene (CYP19) \\ Inactivating mutations in the glucocorticoid receptor gene (GR) \\ Congenital Adrenal hypoplasia (DAX-1 mutation)
}


cal manifestation. Estradiol levels can be remarkably elevated, accompanied by suppressed levels of gonadotropin. The pelvic US generally allows the diagnosis. Mutations in the $\alpha$-subunit of the Gs protein gene have been described in some ovarian tumors (49), as well as mutations in the FSH receptor gene (FSHR) (50).

\section{Ovarian follicular cysts}

Follicular cysts secrete estrogens that cause mammary development or even acyclic vaginal bleeding. They can be recurrent, causing a transitory rise of estradiol levels. Larger follicular cysts can present torsion of the pedicle and infarction, requiring surgical intervention. Germline mutations in the FSH receptor gene (FSHR) were not found in girls with precocious puberty due to ovarian cysts (5l), although somatic mutations were not excluded.

\section{Hypothyroidism}

Primary hypothyroidism causing sexual precocity has been described for many years in severe and long-term untreated primary hypothyroidism associated with multiple ovarian cysts. The in vitro demonstration that human TSH acts on the wild-type human FSH receptor, and that the response is not dependent upon the human FSH receptor isoform, suggests a mechanism to explain the precocious puberty in hypothyroidism accompanied by extremely increased TSH levels $(52,53)$.

\section{Monogenic causes of sexual precocity}

From an etiological point of view, in contrast with GDPP, several genetic causes have been identified (54).

\section{Mutations in the CYP21A2 gene}

21 -hydroxylase deficiency is responsible for more than 95\% of the cases of congenital adrenal hyperplasia $(\mathrm{CAH})$, which is one of the most common autosomal recessive disorders. Different CYP21A2 mutations cause variable degrees of enzymatic activity impairment, being responsible for the broad spectrum of the clinical manifestations of the disease (55). In the male, the classical form of 21-hydroxylase deficiency determines isosexual gonadotropin-independent precocious puberty, whereas in the female it causes heterosexual GIPP. The nonclassical form of 21-hydroxylase deficiency causes advancement of puberty and bone age in the male. In the female, the manifestations include precocious pubarche, bone age advancement, signs of hy- perandrogenism, menstrual irregularity, polycystic ovaries, acne and hirsutism (55).

\section{Mutations in the CYP11B1 (11-hydroxylase) gene and HSD3B2 (3-hydroxysteroid dehydrogenase 2) gene}

The 11-hydroxylase deficiency is the result of mutations in the CYPIIBI gene and it is clinically characterized by virilization with or without hypertension and hypokalemic alkalosis. The deficiency of $3-\beta \mathrm{HSD} 2$ results from mutations in the HSD $3 B 2$ gene and presents as incomplete masculinization in the male, whereas the genetic female has normal external genitalia or mild clitoromegaly. During childhood, hyperandrogenism signs can occur in both sexes, represented by precocious pubarche $(56)$.

\section{Mutations in the Gs protein $\alpha$-subunit gene}

McCune-Albright syndrome is a heterogeneous clinical condition characterized by a classic triad: gonadotropin-independent isosexual precocious puberty, polyostotic fibrous dysplasia and café-au-lait spots. The molecular basis of McCune-Albright syndrome consists of post-zygotic activating mutations in the Gs protein $\alpha$-subunit gene, leading to mosaicism with a constitutively activated adenylcyclase (57). This missense somatic mutation is almost always characterized by the substitution of an arginine residue in position 201 by histidine or cysteine. Other hyperfunctional endocrinopaties have been described in McCune-Albright syndrome, such as GH and/or prolactin-secreting pituitary adenomas, hyperthyroidism, autonomous adrenal hyperplasia and hypophosphatemic osteomalacia. McCune-Albright syndrome usually occurs sporadically and is more common in girls than in boys (54).

Precocious puberty is independent from gonadotropic stimulation, being diagnosed in girls at an early age. Suppressed gonadotropin levels associated with transitorily high estradiol levels are common hormonal findings. Ovarian cysts (asymmetrical and often bilateral) are identified at ultrasound, resulting from the follicular hyperactivation. The bone disease in McCune-Albright syndrome occurs when the bone marrow cells are affected by mutations in the $\alpha$-subunit of the Gs protein gene. X-rays and bone scan are useful tools to evaluate bone disease. Markers of bone formation and resorption are elevated, mainly if the injuries are multiple. Bisphosphonates have been used in the prevention and treat- 
ment of the bone disease in McCune-Albright syndrome. Pamidronate treatment in children with severe fibrous dysplasia seems to be safe and reduces bone pain, but it has no benefits regarding the control of the cystic lesions $(58)$.

\section{Familial male-limited precocious puberty}

Familial male-limited precocious puberty, also called testotoxicosis, is an autosomal-dominant disease caused by constitutive activating mutations in the human $\mathrm{LH}$ receptor gene (LHR) $(59,60)$. The disease generally presents at around 2-4 years of age with puberty signs, accelerated virilization, excessive growth velocity leading to short stature by the adult age due to the precocious closure of the epiphyses. Testosterone levels are high despite the low levels of basal gonadotropins and prepubertal response after exogenous GnRH-stimulation test. This condition treatment consists of drugs that block the adrenal and testicular synthesis of androgens (ketoconazol) and/or androgenic receptor blockage (cyproterone acetate), estrogen receptor blockers and aromatase inhibitors.

\section{Mutations in the aromatase gene (CYP19)}

The aromatase excess syndrome can cause heterosexual precocious puberty and/or gynecomastia in males and isosexual precocious puberty and/or macromastia in females. The pathophysiology consists of exacerbated non-gonadal conversion of androgens into estrogens resulting in hyperestrogenism (61). Aromatase deficiency causes pre- and post-natal virilization picture associated with precocious pubarche, acne and advancement of the bone age (62).

\section{Inactivating mutations of the glucocorticoid receptor gene}

Inactivating mutations of the glucocorticoid receptor gene cause a compensatory rise of ACTH with increased adrenal androgens and steroids upon mineralocorticoid action. The excessive adrenal androgens can rarely lead to the isosexual gonadotropin-independent precocious puberty in the male and the heterosexual form in the female $(54,63)$. This condition treatment is replacement therapy with high dose synthetic glucocorticoids, such as dexamethasone, without the intrinsic salt-retaining activity (54).

\section{Primary adrenal insufficiency due to DAX-1 (dosage-sensitive sex reversal, adrenal hypoplasia congenita $(A H C)$, critical region on the $X$ chromosome, gene-1, NROB1/AHC) mutation}

Primary adrenal insufficiency is a rare condition in pediatric age, and its association with precocious sexual development is very uncommon $(64,65)$. Domenice et al. described a Brazilian boy with X-linked adrenal hypoplasia congenita due to a new frameshift mutation in the $D A X-1$, of which the first clinical manifestation was isosexual gonadotropin-independent precocious puberty (66). The extremely elevated ACTH levels were supposed to stimulate Leydig cells to secrete testosterone, leading to a GIPP in this boy (66). Therefore, $D A X-1$ mutations in humans can promote a dual effect on pubertal development characterized by GIPP during infancy and childhood followed by hypogonadotropic hypogonadism in adulthood (66).

\section{GIPP TREATMENT}

\section{Surgical treatment}

It is reserved for the previously diagnosed neoplasias, such as adrenal, ovarian or testicular tumors, as well as hCG-producing tumors of which the surgical removal results in regression of the pubertal process. Radiation and chemotherapy can be used depending on the type of tumor and the clinical indication.

\section{Medical treatment}

Drugs that act by blocking the action of sex steroids on its specific receptors or through its synthesis are used. The therapeutic options include progestational, antiandrogen and antiestrogen agents:

\section{Progestational agents}

The use of medroxyprogesterone acetate demonstrates a beneficial effect in testotoxicosis as well as in McCune Albright syndrome in both genders. The mechanism of action of medroxyprogesterone includes suppression of gonadotropin release and a direct effect on gonadal steroidogenesis by blocking several enzymatic steps. The routinely used dose is 10 to $50 \mathrm{mg}$ orally daily or 50 to $100 \mathrm{mg}$ intramuscularly every two weeks, with the doses being titrated according to the clinical-laboratory response. Side effects such as edema, chronic headache, 
weight gain, purple striae and adrenal insufficiency are frequent restricting factors to the clinical application.

\section{Antiandrogen agents}

There are two types: androgen receptor blockers and androgen synthesis inhibitors.

Androgen receptor blockers: this category includes spironolactone and cyproterone acetate. Both drugs have antiandrogenic activity, competing with testosterone for its receptor in peripheral tissues and cyproterone has an additional progestational action at the pituitary level, partially suppressing gonadotropin secretion. The usual daily oral doses are 50 to $100 \mathrm{mg} /$ $\mathrm{m} 2$ for cyproterone acetate and $100 \mathrm{mg}$ for spironolactone. Side effects include: gastrointestinal symptoms and gynecomastia in the male. Laboratory hypoadrenalism can occur with cyproterone use, deserving special attention in stressful situations.

\section{Ketoconazol}

It is an imidazole derivative that inhibits P450cl7 enzyme, which converts 17-hydroxyprogesterone into androstenedione. The average daily oral dose is usually $200 \mathrm{mg}$. Its main side-effect is hepatic injury. Other side effects include gastric intolerance, reversibly elevated serum transaminase levels and laboratory hypoadrenalism (67).

\section{Antiestrogen agents}

There are two types of agents, the estrogen receptor modulators and the estrogen synthesis blockers.

\section{Tamoxifen}

It is a selective estrogen receptor modulator and represents an attractive therapeutic option for the treatment of precocious puberty in McCune-Albright syndrome, showing a decreased frequency of vaginal bleeding episodes, reduced growth velocity and decelerated skeletal maturation. The dose ranges from 10 to $20 \mathrm{mg} /$ day, administered orally (68). Side effects include hepatotoxicity and hypertricosis. A careful hematological, hepatic, renal and electrolytic follow-up must be carried out quarterly.

\section{Aromatase inhibitors}

The aromatase inhibitors block the conversion of androgens into estrogens. Highly selective aromatase inhibitors, such as anastrozole and letrozole, have shown to be promising in the treatment of the GIPP in both sexes, with few side effects $(69,70)$. Recently, a pilot study including nine girls with McCune Albright syndrome has suggested letrozole may be an effective therapy for this condition (70). Mean ovarian volume, estradiol levels, and markers of bone metabolism fell significantly after 6 months but tended to rise by 24-36 months (70). In contrast, uterine volumes did not change (70). However, in our experience these drugs did not prevent estradiol production in 5 girls with McCune-Albright syndrome (71).

The association of an antiandrogen agent (cyproterone or spironolactone) with an aromatase inhibitor seems attractive despite the high cost. When using drugs that inhibit the action of sex steroids such as cyproterone and tamoxifen, gonadotropin and sex steroid measurements do not represent good parameters for the therapeutic efficacy control. Clinical parameters should be always used to monitor GIPP therapy efficacy.

\section{GnRH agonist analogues}

Secondary GDPP is well controlled with the addition of depot aGnRH. Finally, GIPP treatment in both sexes has to be individualized and based on the different action mechanisms of the available therapeutic options.

\section{ACKNOWLEDGMENTS}

This study was support by Universidade de São Paulo, Fundação Faculdade de Medicina Grant to VNB and Conselho Nacional de Desenvolvimento Científico e Tecnológico (CNPq) Grants to ACL, IJPA and BBM (process numbers: 300469/2005-5, 200938/2006-3 and $300828 / 2005-5$, respectively).

The authors express their gratitude to Ms. Sonia Strong for the English review.

\section{REFERENCES}

1. Partsch CJ, Heger S, Sippell WG. Management and outcome of central precocious puberty. Clin Endocrinol (Oxf). 2002; 56:129-48.

2. Herman-Giddens ME, Slora EJ, Wasserman RC, Bourdony CJ, Bhapkar MV, Koch GG, et al. Secondary sexual characteristics and menses in young girls seen in office practice: a study from the Pediatric Research in Office Settings network. Pediatrics. 1997; 99:505-12. 
3. Midyett LK, Moore WV, Jacobson JD. Are pubertal changes in girls before age 8 benign? Pediatrics. 2003; 111:47-51.

4. Crofton PM, Evans NE, Wardhaugh B, Groome NP, Kelnar CJ. Evidence for increased ovarian follicular activity in girls with premature thelarche. Clin Endocrinol. 2005; 62:205-9.

5. De Vries L, Horev G, Schwartz M, Phillip M. Ultrasonographic and clinical parameters for early differentiation between precocious puberty and premature thelarche. Eur $\mathrm{J}$ Endocrinol. 2006; 154:891-8.

6. Pasquino AM, Pucarelli I, Passeri F, Segni M, Mancini MA, Municchi G. Progression of premature thelarche to central precocious puberty. J Pediatr. 1995; 126:11-4.

7. Neville KA, Walker JL. Precocious pubarche is associated with SGA, prematurity, weight gain, and obesity. Arch Dis Child. 2005; 90: 258-261.

8. Ibáñez L, Potau N, Marcos MV, Zegher F. Exaggerated adrenarche and hyperinsulinism in adolescent girls born small for gestational age. J Clin Endocrinol Metab. 1999; 84:4739-41.

9. Ong K, Potau N, Petry CJ, Jones R, Ness AR, Honour JW, et al. Opposing Influences of Prenatal and Postnatal Weight Gain on Adrenarche in Normal Boys and Girls. J Clin Endocrinol Metab. 2004; 89:2647-51.

10. Banerjee I, Clayton P. The genetic basis for the timing of human puberty. J Neuroendocrinol. 2007; 19(11):831-8.

11. Teles M, Bianco SC, Brito VN, Trarbach E, Seminara SB, Arnhold IJP, et al. An activating mutation in GPR54 causes gonadotropin-dependent precocious puberty. Proceedings of the $88^{\text {th }}$ Annual Meeting of the Endocrine Society. Boston MA: Endocrine Society, 2006: OR34-3.

12. Silveira LG, Santos MAG; Brito VN, Arnhold IJP, Mendonca, $\mathrm{BB}$, Latronico AC. In vitro study of a KiSS1 gene missense mutation identified in a boy with idiopathic gonadotropin-dependent precocious puberty. Proceedings of the $89^{\text {th }}$ Annual Meeting of the Endocrine Society.Toronto: Endocrine Society. 2007; P2-459.

13. Brito VN, Latronico AC, Arnhold IJ, Lo LS, Domenice S, Albano $\mathrm{MC}$, et al. Treatment of gonadotropin dependent precocious puberty due to hypothalamic hamartoma with gonadotropin releasing hormone agonist depot. Arch Dis Child. 1999; 80:231-4.

14. Jung H, Carmel P, Schwartz MS, Witkin JW, Bentele KHP, Westphal M, et al. Some hypothalamic hamartomas contain transforming growth factor $\alpha$, a puberty-inducing growth factor, but not luteinizing hormone-releasing hormone neurons. J Clin Endocrinol Metab. 1999; 84:4695-701.

15. Marshall WA, Tanner JM. Variations in pattern of pubertal changes in girls. Arch Dis Child. 1969; 44:291-303.

16. Marshall WA, Tanner JM. Variations in the pattern of pubertal changes in boys. Arch Dis Child. 1970; 45:13-23.

17. Brito VN, Batista MC, Borges MF, Latronico AC, Kohek MBF, Thirone AC et al. Diagnostic value of fluorometric assays in the evaluation of precocious puberty. J Clin Endocrinol Metab. 1999; 84:3539-44.

18. Brito VN, Latronico AC, Arnhold IJ, Mendonca BB. A single luteinizing hormone determination 2 hours after depot leuprolide is useful for therapy monitoring of gonadotropin-dependent precocious puberty in girls. J Clin Endocrinol Metab. 2004; 89:4338-42.

19. Bhatia S, Neely EK, Wilson DM. Serum luteinizing hormone rises within minutes after depot leuprolide injection: implications for monitoring therapy. Pediatrics. 2002; 109:E30.
20. Resende EA, Lara BH, Reis JD, Ferreira BP, Pereira GA, Borges MF. Assessment of Basal and Gonadotropin-Releasing Hormone-Stimulated Gonadotropins by Immunochemiluminometric and Immunofluorometric Assays in Normal Children. J Clin Endocrinol Metab. 2007; 92: 1424-9.

21. Neely EK, Hintz RL, Wilson DM, Lee PA, Gautier T, Argente J, et al. Normal ranges for immunochemiluminometric gonadotropin assays. J Pediatr. 1995; 127:40-6.

22. Oerter KE, Uriarte MM, Rose SR, Barnes KM, Cutler Jr GB. Adult height in precocious puberty after long-term treatment with deslorelin. J Clin Endocrinol Metab. 1991; 73:1235-40.

23. Cavallo A, Richards GE, Busey S, Michaels SE. A simplified gonadotrophin-releasing hormone test for precocious puberty. Clin Endocrinol (Oxf). 1995; 42:641-6.

24. Eckert KL, Wilson DM, Bachrach LK, Anhalt H, Habiby RL, Olney RC, et al. A single-sample, subcutaneous gonadotropinreleasing hormone test for central precocious puberty. Pediatrics. 1996; 97:517-9.

25. Parent AS, Teilmann G, Juul A, Skakkebaek NE, Toppari J, Bourguignon JP. The timing of normal puberty and the age limits of sexual precocity: variations around the world, secular trends, and changes after migration. Endocr Rev. 2003; 24:668-93.

26. Heger S, Sippell WG, Partsch CJ. Gonadotropin-releasing hormone analogue treatment for precocious puberty. Twenty years of experience. Endocr Dev. 2005; 8:94-125.

27. Carel JC, Lahlou N, Jaramillo O, Montauban V, Teinturier C, Colle M, et al. Treatment of central precocious puberty by subcutaneous injections of leuprorelin 3-month depot (11.25 mg). $\mathrm{J}$ Clin Endocrinol Metab. 2002; 87:4111-6.

28. Trueman JA, Tillmann V, Cusick CF, Foster P, Patel L, Hall CM et al. Suppression of puberty with long-acting goserelin (Zoladex-LA): effect on gonadotrophin response to $\mathrm{GnRH}$ in the first treatment cycle. Clin Endocrinol (Oxf). 2002; 57(2):223-30

29. Brito VN, Monteiro KC, Mendonca BB, Latronico AC, Arnhold IJ. Uso trimestral de acetato de leuprolide $(11,25 \mathrm{mg})$ no controle hormonal da puberdade precoce dependente de gonadotrofinas. IV COPEM - Congresso Paulista de Endocrinologia e Metabologia. Arq Bras Endocrinol Metab. 2001; 45: PO 07.

30. Hirsch HJ, Gillis D, Strich D, Chertin B, Farkas A, Lindenberg T, et al. The histrelin implant: a novel treatment for central precocious puberty. Pediatrics. 2005; 116(6):e798-802.

31. Eugster EA, Clarke W, Kletter GB, Lee PA, Neely EK, Reiter EO, et al. Efficacy and safety of histrelin subdermal implant in children with central precocious puberty: a multicenter trial. J Clin Endocrinol Metab. 2007; 92(5):1697-704.

32. Tonini G, Marinoni S, Forleo V. Local reactions to luteinizing hormone releasing hormone analog therapy. J Pediatr. 1995; 126:150-60.

33. Palmert MR, Mansfield MJ, Crowley Jr. WF, Crigler Jr JF, Crawford JD, Boepple PA. Is Obesity an Outcome of GonadotropinReleasing Hormone Agonist Administration? Analysis of Growth and Body Composition in 110 Patients with Central Precocious Puberty. J Clin Endocrinol Metab. 1999; 84: 4480-8.

34. Parker KL, Baens-Bailon RG, Lee PA. Depot leuprolide acetate dosage for sexual precocity. J Clin Endocrinol Metab. 1991 73:50-2.

35. Cook JS, Doty KL, Conn PM, Hansen JR. Assessment of depot leuprolide acetate dose-adequacy for central precocious puberty. J Clin Endocrinol Metab. 1992; 74:1206-9.

36. Witchel SF, Baens-Bailon RG, Lee PA. Treatment of central precocious puberty: comparison of urinary gonadotropin excretion and gonadotropin-releasing hormone $(\mathrm{GnRH})$ stimulation 
tests in monitoring $\mathrm{GnRH}$ analog therapy. J Clin Endocrinol Metab. 1996; 81:1353-6.

37. Lawson ML, Cohen N. A single sample subcutaneous luteinizing hormone (LH)-releasing hormone (LHRH) stimulation test for monitoring LH suppression in children with central precocious puberty receiving LHRH agonists. J Clin Endocrinol Metab. 1999; 84:4536-40.

38. Badaru A, Wilson DM, Bachrach LK, Fechner P, Gandrud LM, Durham E, et al. Sequential comparisons of one-month and three-month depot leuprolide regimens in central precocious puberty. J Clin Endocrinol Metab. 2006; 91(5):1862-7.

39. Lazar L, Pertzelan A, Weintob N, Philipp M, Kauli R. Sexual precocity in boys: accelerated versus slowly progressive puberty gonadotropin-suppressive therapy and FH. J Clin Endocrinol Metab. 2001; 86(9):4127-32.

40. Rizzo V, De Sanctis V, Corrias A, Fortini M, Galluzzi F, Bertelloni $\mathrm{S}$, Guarneri MP, et al. Factors influencing final/near $\mathrm{FH}$ in 12 boys with central precocious puberty treated with gonadotropin-releasing hormone agonists. Italian Study Group of Physiopathology of Puberty. J Pediatr Endocrinol Metab. 2000: 13(1): 781-6.

41. Mul D, Bertelloni S, Carel JC, Saggese G, Chaussain JL, Oostdijk W. Effect of gonadotropin-releasing hormone agonist treatment in boys with central precocious puberty: $\mathrm{FH}$ results. Horm Res. 2002; 58(1):1-7.

42. Heger S, Partsch CJ, Sippell WG. Long-term outcome after depot releasing hormone agonist treatment of central precocious puberty: final height, body proportions, body composition, bone mineral density, and reproductive function. J Clin Endocrinol Metab. 1999; 84: 4583-90.

43. Antoniazzi F, Zamboni G, Bertoldo F, Lauriola S, Mengarda F, Pietrobelli $A$, et al. Bone mass at final height in precocious puberty after gonadotropin-releasing hormone agonist with and without calcium supplementation. J Clin Endocrinol Metab. 2003; 88(3):1096-101.

44. Pasquino AM, Municchi G, Pucarelli I, Segni M, Mancini MA, Troiani S. Combined treatment with gonadotropin-releasing hormone analog and growth hormone in central precocious puberty. J Clin Endocrinol Metab. 1996; 81:948-51.

45. Pucarelli I, Segni M, Ortore M, Arcadi E, Pasquino AM. Effects of combined gonadotropin-releasing hormone agonist and growth hormone therapy on adult height in precocious puberty: a further contribution. J Pediatr Endocrinol Metab. 2003; 16:1005-10.

46. Vottero A, Pedori S, Verna M, Pagano B, Cappa M, Loche S, et al. Final height in girls with central idiopathic precocious puberty treated with gonadotropin-releasing hormone analog and oxandrolone. J Clin Endocrinol Metab. 2006; 91: 1284-7.

47. Roth C. Therapeutic potential of GnRH antagonists in the treatment of precocious puberty. Expert Opin Investig Drugs. 2002; 11(9):1253-9.

48. d'Alva CB, Brito VN, Palhares HM, Carvalho FM, Arnhold IJ, Mendonca BB, et al. A single somatic activating Asp578His mutation of the luteinizing hormone receptor causes Leydig cell tumour in boys with gonadotropin-independent precocious puberty. Clin Endocrinol (Oxf). 2006; 65(3):408-10.

49. Fragoso MC, Latronico AC, Carvalho FM, Zerbini MC, Marcondes JAM, Araujo LM, et al. Activating mutation of the stimulatory $\mathrm{G}$ protein (gsp) as a putative cause of ovarian and testicular human stromal Leydig cell tumors. J Clin Endocrinol Metab. 1998; 83:2074-8.

50. Kotlar TJ, Young RH, Albanese C, Crowley WF, Scully RE, Jameson JL. A mutation in the follicle-stimulating hormone re- ceptor occurs frequently in human ovarian sex cord tumors. J Clin Endocrinol Metab. 1997; 82:1020-6.

51. Batista MC, Kohek MB, Frazzatto ES, Fragoso CM, Mendonca $\mathrm{BB}$, Latronico AC. Mutation analysis of the follicle-stimulating hormone receptor gene in girls with gonadotropin-independent precocious puberty resulting from autonomous cystic ovaries. Fertil Steril. 2000; 73:280-3.

52. Anasti JN, Flack MR, Froehlich J, Nelson LM, Nisula BC. A potential novel mechanism for precocious puberty in juvenile hypothyroidism. J Clin Endocrinol Metab. 1995; 80:276-9.

53. Ryan GL, Feng X, d'Alva CB, Zhang M, Van Voorhis BJ, Pinto $E M$, et al. Evaluating the Roles of Follicle-Stimulating Hormone Receptor Polymorphisms in Gonadal Hyperstimulation Associated with Severe Juvenile Primary Hypothyroidism J Clin Endocrinol Metab. 2007; 92: 2312-7.

54. Kalantaridou SN, Chrousos GP. Clinical review 148: Monogenic disorders of puberty. J Clin Endocrinol Metab. 2002; 87:2481-94.

55. Bachega TA, Billerbeck AE, Madureira G, Marcondes JAM, Longui CA, Leite MV, et al. Molecular genotyping in Brazilian patients with the classical and nonclassical forms of 21-hydroxylase deficiency. J Clin Endocrinol Metab. 1998; 83:4416-9.

56. Marui S, Torrealba IM, Russell AJ, Latronico AC, Sutcliffe RG, Mendonca BB. A novel homozygous nonsense mutations E135* in the type II 3beta-hydroxysteroid dehydrogenase gene in a girl with salt-losing congenital adrenal hyperplasia. Mutations in brief no. 168. Online. Hum Mutat. 1998; 12:139.

57. Weinstein LS, Shenker A, Gejman PV, Merino MJ, Friedman E, Spiegel AM. Activating mutations of the stimulatory $\mathrm{G}$ protein in the McCune-Albright syndrome. N Engl J Med. 1991; 325:1688-95.

58. Plotkin H, Rauch F, Zeitlin L, Munns C, Travers R, Glorieux FH. Effect of pamidronate treatment in children with polyostotic fibrous dysplasia of bone. J Clin Endocrinol Metab. 2003; 88:4569-75.

59. Laue L, Chan WY, Hsueh AJ, Kudo M, Hsu SY, Wu S, et al. Genetic heterogeneity of constitutively activating mutations of the human luteinizing hormone receptor in familial male-limited precocious puberty. Proc Natl Acad Sci U S A. 1995; 92:1906-10.

60. Latronico AC, Shinozaki H, Guerra G Jr, Pereira MA, Maini SH, Baptista MT, et al. Gonadotropin-independent precocious puberty due to luteinizing hormone receptor mutations in Brazilian boys: a novel constitutively activating mutation in the first transmembrane helix. J Clin Endocrinol Metab. 2000; 85(12): 4799-805.

61. Martin RM, Lin CJ, Nishi MY, Billerbeck AEC, Latronico AC Russel DW, et al. Familial hyperestrogenism in both sexes: clinical, hormonal, and molecular studies of two siblings. J Clin Endocrinol Metab. 2003; 88:3027-34.

62. Morishima A, Grumbach MM, Simpson ER, Fischer C, Qin K. Aromatase deficiency in male and female siblings caused by a novel mutation and the physiological role of estrogens. J Clin Endocrinol Metab. 1995; 80(12):3689-98.

63. Mendonca BB, Leite MV, de Castro M, Tomoshige K, Elias LLK, Bachega TA, et al. Female pseudohermaphroditism caused by a novel homozygous missense mutation of the GR gene. J Clin Endocrinol Metab. 2002; 87(4):1805-9.

64. Bertrand J, Loras S, Saez J, Forest M, Peretti E, Jeune M. Precocious puberty during chronic adrenal insufficiency. Another example of complex drag-effect endocrinopathy. Ann Pediatr. $1965 ; 12: 772-7$. 
65. Marilus R, Dickerman Z, Kaufman H, Versano I, Laron Z Addison's disease associated with precocious sexual development in a boy. Acta Pediatr Scand. 1981; 70:587-9.

66. Domenice S, Latronico AC, Brito VN, Arnhold IJP, Kok F, Mendonca BB. Adrenocorticotropin-dependent precocious puberty of testicular origin in a boy with X-linked adrenal hypoplasia congenita due to a novel mutation in the DAX1 gene. J Clin Endocrinol Metab. 2001; 86:4068-71.

67. Soriano-Guillén L, Lahlou N, Chauvet G, Roger M, Chaussain $\mathrm{JL}$, Carel JC. Adult Height after Ketoconazole Treatment in $\mathrm{Pa}$ tients with Familial Male-Limited Precocious Puberty J Clin Endocrinol Metab. 2005; 90: 147-151.

68. Eugster EA, Rubin SD, Reiter EO, Plourde P, Jou HC, Pescovitz $\mathrm{OH}$, et al. Tamoxifen treatment for precocious puberty in McCune-Albright syndrome: a multicenter trial. J Pediatr. 2003; 143:60-6.

69. Feuillan P, Merke D, Leschek EW, Cutler GB Jr. Use of aromatase inhibitors in precocious puberty. Endocr Relat Cancer. 1999; 6:303-6.

70. Feuillan P, Calis K, Hill S, Shawker T, Robey PG, Collins MT. Letrozole Treatment of Precocious Puberty in Girls with the
McCune-Albright Syndrome: A Pilot Study J Clin Endocrinol Metab. 2007; 92: 2100-6.

71. D'Alva CB, Latronico AC, Brito VN, Teles M, Arnhold IJ, Mendonca BB. Diagnosis and treatment of girls with gonadotropin-independent precocious puberty due to autonomous ovarian cysts. In: XVII Encontro da SLEP - Sociedade LatinoAmericana de Endocrinologia Pediatrica. J Ped Endocrinol Metab. 2004; 17:1355.

\section{Address for correspondence:}

Vinicius Nahime Brito

Hospital das Clínicas, Faculdade de Medicina da Universidade de São Paulo, Disciplina de Endocrinologia e Metabologia

Av. Dr. Eneas de Carvalho Aguiar, $1552^{\circ}$ andar Bloco 6 05403-900, São Paulo, SP, Brazil

e-mail: vinbrito@uol.com.br; beremen@usp.br 